\title{
ウイルス除去用中空糸（BMM）の免疫 グロブリン製剤製造工程への応用
}

\begin{tabular}{|c|c|c|c|c|}
\hline 定美1) & 伊藤 & 碩侯 ${ }^{1)}$ & 竹内 & 次雄 ${ }^{1)}$ \\
\hline 政一1) & 石川 & 元 $^{2)}$ & 鶴見 & 隆 ${ }^{2)}$ \\
\hline 誠司2) & 佐谷 & 壭州夫2) & 山旉 & 駿2) \\
\hline
\end{tabular}

1）日本赤十字社血浆分画センター

2）旭化成工業株式会社

（昭和63年 8 月 26 日受付）

\section{APPLICABILITY OF THE HOLLOW FIBER FOR VIRUS REMOVAL (BMM) TO MANUFACTURING PROCESS OF GLOBULIN FROM POOLED PLASMA}

Sadayoshi Sekiguchi ${ }^{1)}$, Hiroyoshi Itoh ${ }^{1)}$, Tsugio Takeuchi ${ }^{1)}$, Hisashi Kutsuzawa ${ }^{1)}$, Masaichi Ohta ${ }^{1)}$, Gen Ishikawa ${ }^{2)}$, Takashi Tsurumi ${ }^{2)}$, Naoki Ohsawa ${ }^{2)}$, Seiji Fukada ${ }^{2)}$,

Masuo Satani ${ }^{2)}$ and Takashi Yamashiki ${ }^{21}$

1) Japanese Red Cross Plasma Fractionation Center

2) Asahi Chemical Ind. Co. Ltd.

The applicability of BMM to Cohn's fractionation process for manufacturing immunoglobulin preperation was investigated from the view point of filtration characteristics such as the values of filtration-capacity (FC), and of sieving-coefficient (SC) of protein, and of the change in electrophoretic pattern (EP) according to filtration.

The filtration conditions for the intermediate products was settled so as to fit the acutual manufacturing conditions.

For the semifinal products, the dependences of FC, SC and EP on the filtration-temperature (FT), protein-concentration (PC) and the mean pore size of BMM $\left(2 \overline{\mathbf{r}}_{\mathrm{f}}\right)$ were evaluated.

The values of FC and SC increased when the intermediate products approached to the final one or $2 \overline{\mathbf{r}}_{\mathrm{f}}$ increased or FT elevated or PC decreased.

We concluded that BMM was applicable for the liquid before dispensing into a bottle and for the supernatant-II-3.

\section{序言}

免疫グロブリン製剤の製造工程では，通常加熱 処理が実施されていない。これはCohnの冷ェタ ノール分画法で製造された製剤については，経験 的に B 型肝炎ウイルス (HBV) の感染の報告がな かったことに起因している. しかし近年, 硫安法, リバノール硫安法, DEAE Sephadex 法等, 種々 の分画法により免疫グロブリン製剤が製造される ようになり，HBV，エイズウイルス (HIV) 及び 非 $\mathrm{A}$ 非 $\mathrm{B}$ 肝炎ウイルスによる感染の報告1) 3)
散見されるようになった。血液中に混入する恐れ のあるウイルスを除去する事を目的として，ウイ ルス除去用中空系(旭化成工業株式会社製 BMM) が開発された。除去すべき目標ウイルスの直径に 対して, 水濾過速度法による平均孔径 $\left(2 \overline{\mathbf{r}}_{\mathrm{f}}\right)$ がわ ずかに下回る BMM で濾過すれば, 濾液中の目標 ウイルス濃度を検出限界以下にすることができ る4).前報5)では Cohn 法による血漿分画工程, 特に アルブミン製剂の製造工程に BMM の適用の可 能性を検討した. その結果, FV-1 及び分注前の工 
程ではアルブミンの透過率 $95 \%$ 以上，濾過速度 30 $l / \mathrm{m}^{2} \cdot \mathrm{hr}$, 濾過容量 (有効膜面積 $1 \mathrm{~m}^{2}$ 当りの濾過量) $80 \mathrm{l} / \mathrm{m}^{2}$ 以上となり，BMM は工業的にも適用可能 であることを明らかにした。一方，再生セルロー スを構成成分とする BMM の濾過性能は共存す る蛋白組成の影響のみでなく，エタノール濃度， 濾過温度の影響を強く受ける。アルブミンの場合 に比較して，免疫グロブリン製剤の製造工程中の エタノール濃度, 分画温度, 共存蛋白が何れも異 なり，また免疫グロブリンの分子量はアルブミン のそれよりも大きい，そのため，BMM が免疫グ ロブリン製剤製造工程に拈いて適用できるかどう かは，アルブミン製剤の場合と比較してはるかに 困難な条件にあることがわかる，本論文では Cohn 法による免疫グロブリン製造工程中への BMM の適用性を検討した。

\section{実験}

材料：(1) ウイルス除去用中空糸 (BMM)；セ ルロース銅アンモニア溶液からミクロ相分離法6) により, 水流速平均孔径が $30,50 \mathrm{~nm}$ の BMM を作 製した。（2）分画工程の中間製品; Cohn 法の免 疫グロブリン分面工程中の supernatant-I (SI), filtrated supernatant-III by depth filtration
（SFIII), supernatant-II-3 (SII-3) 及び最終製品を 用いた。

方法：予備実験により得られた濾過速度と濾過 圧力, 濾過時間曲線との関係から最適な濾過速度 を決定した。これにより得られた濾過速度で一次 側から二次側へ完全濾過する方式(垂直濾過方式) にて濾過を行い，一次圧が $1 \mathrm{~kg} / \mathrm{cm}^{2}$ に到達するま でに可能な処理量をその条件下での濾過容量とし た。さらに濾過温度, 蛋白濃度, BMM の平均孔 径を变えて実験を行い, 濾過容量, 蛋白透過率, 高速液体クロマトグラフィー(HPLC)及び電気泳 動（EP）を実施し各条件下での評価を行った。

\section{成 績}

表一 1 に免疫グロブリン製剤の製造工程での各 ステップに拈ける濾過性能をまとめて示す。この 表より以下のことが明かである. (1) 水流速平均孔 径が30nmから $50 \mathrm{~nm}$ に上昇すると何れのステッ プに扣いても濾過容量は大幅に増大し, 蛋白透過 率も高くなる. (2) 同様に最終製品に近づく程, 濾 過容量, 蛋白透過率は増加する. (3) 濾過温度を高 くすることにより，免疫グロブリン製剤の濾過性 能は上昇した。(4) BMM 濾過前にあらかじめ除菌 フィルター $(0.22 \mu \mathrm{m})$ を用いると濾過性能は上昇

Table 1 Filtration characteristics of BMM 30 and 50 for solution of intermediate products and solution of immunoglobulin ;

\begin{tabular}{|c|c|c|c|c|c|c|c|c|}
\hline \multirow[b]{2}{*}{$\begin{array}{l}\text { Intermediate } \\
\text { product }\end{array}$} & \multirow[b]{2}{*}{$\begin{array}{l}\text { Filtration } \\
\text { temperature } \\
\text { ('C) }\end{array}$} & \multirow[b]{2}{*}{$\begin{array}{c}\text { Mean pore size } \\
\text { of } \mathrm{BMM} \\
(\mathrm{nm})\end{array}$} & \multicolumn{6}{|c|}{ Filtration characteristics } \\
\hline & & & $\begin{array}{l}\text { Filtration } \\
\text { Shear rate } \\
\left(\mathrm{Sec}^{-1}\right)\end{array}$ & $\begin{array}{l}\text { Filtration } \\
\text { Capacity } \\
\left(l / \mathrm{m}^{2}\right)\end{array}$ & $\begin{array}{l}\text { Filtration } \\
\text { rate } \\
\left(\mathrm{ml} / \mathrm{m}^{2}\right. \\
\mathrm{min})\end{array}$ & $\begin{array}{l}\text { Sieving coefficient } \\
\text { of immunoglobulin } \\
(\%)\end{array}$ & $\begin{array}{c}\text { Total } \\
\text { protein } \\
\left(\mathrm{g} / \mathrm{m}^{2}\right)\end{array}$ & $\begin{array}{l}\text { Change in } \\
\text { electphoretic } \\
\text { pattern }\end{array}$ \\
\hline \multirow{2}{*}{ SI } & \multirow{2}{*}{-3} & 30 & 0 & 1.1 & 7.6 & 26 & 16.2 & Decrease in $\alpha_{2}$ \\
\hline & & 50 & 0 & 1.6 & 8.2 & 40 & 36.8 & Decrease in $\alpha_{2}$ \\
\hline SFIII & -5 & 50 & 0 & 10 & 267 & 94 & 64 & \\
\hline \multirow{2}{*}{ SII-3 } & \multirow{2}{*}{-5} & 30 & 0 & 3.7 & 353 & 63 & 3.7 & \\
\hline & & 50 & 0 & 120 & 726 & 100 & 231 & \\
\hline \multirow{2}{*}{ globulin $15 \%$} & +4 & 50 & 0 & 0.17 & 22.3 & 22 & 4.8 & \\
\hline & +20 & 50 & 0 & 1.33 & 107 & 100 & 177 & \\
\hline globulin $5 \%$ & +20 & 50 & 0 & 29 & 187 & 98 & 1701 & \\
\hline \multirow{2}{*}{$\begin{array}{c}\text { after the } \\
0.22 \mu \mathrm{m} \\
\text { globulin } 5 \%\end{array}$} & \multirow{2}{*}{+20} & 30 & 0 & 1.67 & 87 & 45 & 42 & \\
\hline & & 50 & 0 & 40 & 1087 & 100 & 2080 & \\
\hline \multirow{2}{*}{$\begin{array}{l}\text { pepsin treated } \\
\text { globulin } 5 \%\end{array}$} & \multirow{2}{*}{+20} & 30 & 0 & 17 & 467 & 98 & 1002 & \\
\hline & & 50 & 0 & 60 & 1873 & 98 & 3522 & \\
\hline
\end{tabular}


した. (5) 特に, ペプシン処理後の溶液では高い濾 過性能を示した. (6) 濾過前後での HPLCによる polymer, dimerの混入割合については差は認め られなかったが，残液を見ると重合体が若干濃縮 されていた。

\section{考 察}

濾過中のウイルス濃度を低下させるには BMM の平均孔径を小さくすればよい。この時, $\mathrm{SC}, \mathrm{FC}$ は低下する，従って，具体的に適用される工程に 最適な平均孔径の BMM を設計に組み込むべき である、免疫グロブリン製剤の BMM 濾過前後で 高速液体クロマトグラフィーのパターンが変化し ていないことにより, 重合化した免疫グロブリン もほ㜔全に BMM を透過しているといえる。ウ イルスのカプシドは蛋白質であるから逆にウイル ス径がある臨界値以下になると BMM のウイル ス阻止が不可能になることが予想される。このよ らな蛋白透過性及びウイルス阻止性能を支配する 臨界粒子径の存在は BMM の製膜原理と関連が あると考えられる. BMM の濾過性能は濾過温度 の影響を大幅に受ける.濾過温度の低下に伴って, (1) エタノール水溶液の粘度の増大, (2) 溶液中の 凝集体の増加（除菌フィルターの効果及び $\mathrm{BMM}$ の濾過性能からみて, 直径 $0.1 \sim 1 \mu \mathrm{m}$ と推定), (3) 溶液中での蛋白質の拡散速度が小さくなるためと 推測される，濾過温度の変化による FC, FR の影 響は溶液の粘度変化だけでは説明がつかず，粘度 以外の原因，たとえばアルコール及び水の混合系 での中空糸内に括ける壁面での濃度差等も考号ら れる. 蛋白質の濃度が増大すると BMM の濾過性 能が低下する，この原因として濾過温度と同様に 濃度増加に伴って，上記(1)，(2)，(3)の原因が考え
られる。

$$
\text { むすび }
$$

ウイルス除去機能をもつ BMM は人血漿由来 の蛋白質の透過性が大きいため，工業的に血漿分 画製造工程へも適用可能である。免疫グロブリン 製剂製造工程への応用については, 精製度の高い, 最終工程での $0.22 \mu \mathrm{m}$ 後, あるいはペプシン処理 後の溶液について適用可能である. BMM の $30 \mathrm{~nm}$ により濾過除去されるウイルス種としては HIV, $\mathrm{HBV}$ が確認されているが，ウイルス径が40nm 以 上のものについては検出限界以下まで除去されて いるものと考觉られる。

\section{文献}

1) Trepo, C., Hantz, O. and Vitvitaki, L.: NonA, Non-B Hepatitis after intravenous Gammaglobulin. Lancet, I 322, 1986.

2) Webster, A.D.B. and Lever, A.M.L.: Non-A, Non-B Hepatitis after intravenous Gammglobulin. Lancet, I 322, 1986.

3) Lever, A.M.L., Webster, A.D.B., Brown, D. and Thomas, H.C.: Non-A, Non-B Hepatitis occuring in Agammaglobulinemic patients after intravenous Immunoglobulin Lancet, II 1062 $-1064,1984$.

4）伊藤敬三, 小林正友, 池田久實, 関口定美, 飯島 秀樹, 鶴見 隆, 石川 元, 真鍋征一, 相沢 秀: BMM 中空糸による盤漿中のウイルス除去の可能 性。医学のあゆみ, $142: 53-54,1987$.

5）関口定美，伊藤碩侯，竹内次雄，沓沢久史，石川 元, 鶴見 隆, 大沢直樹, 深田誠二, 佐谷満州夫, 山敷 駿：ウイルス除去用中空系 $(B M M)$ のアル ブミン製造工程への応用. 医学のあゆみ，146： $859-860,1988$.

6) Kamide, K. and Manabe, S.: "Role of microphase separation phenomena in the formation of porous polymeric membrane". Am. Chem. Soc. 9 : 197-228, 1985. 